\title{
sciendo
}

\section{THE EFFECTS OF FISH FEED SUPPLEMENTED WITH $A Z O L L A$ MEAL ON THE GROWTH PERFORMANCE, DIGESTIVE ENZYME ACTIVITY, AND HEALTH CONDITION OF GENETICALLY-IMPROVED FARMED TILAPIA (OREOCHROMIS NILOTICUS)}

Fawzy I. Magouz ${ }^{1}$, Mahmoud A.O. Dawood ${ }^{1 \star}$, Mahmoud F.I. Salem², Ayman A.I. Mohamed ${ }^{1}$

${ }^{1}$ Department of Animal Production, Faculty of Agriculture, Kafrelsheikh University, 33516, Kafrelsheikh, Egypt

${ }^{2}$ Central Laboratory for Aquaculture Research, Abbassa, Sharkia, Sakha Aquaculture Research Unit, Kafrelsheikh, Egypt

•Corresponding author: mahmouddawood55@gmail.com

\begin{abstract}
Azolla meal was included in fish feed at different levels $(10 \%, 20 \%$, and $30 \%)$ and was fed to genetically-improved farmed tilapia (GIFT) for 90 days. The obtained results demonstrated that the final body weight, weight gain, and specific growth rate decreased significantly in fish fed $30 \%$ Azolla $(\mathrm{P}<\mathbf{0 . 0 5})$, while tilapia fed $\mathbf{1 0 \%}$ and $\mathbf{2 0 \%}$ did not differ significantly from those of the control $(\mathrm{P}>\mathbf{0 . 0 5})$. However, the feed conversion ratio increased significantly in fish fed $30 \%$ Azolla $(\mathrm{P}<\mathbf{0 . 0 5})$, while tilapia fed $\mathbf{1 0 \%}$ and $20 \%$ did not differ significantly from those of the control $(\mathrm{P}>0.05)$. The body proximate analysis, amylase, lipase, protease, blood phagocytic index, and phagocytic and lysozyme activity were not affected by the inclusion of Azolla in tilapia diets and remained similar to those of the control group $(\mathrm{P}>0.05)$. The villus length of the foregut was not significantly affected by Azolla inclusion in tilapia diets $(\mathrm{P}>0.05)$. In the midgut, the villus length significantly $(\mathrm{P}<0.05)$ increased in fish fed Azolla at $20 \%$ and $30 \%$ compared to the control, with no differences from those fed at $10 \%(P>0.05)$. The villus length significantly $(P<0.05)$ increased in the hind gut in fish fed Azolla at $30 \%$ compared to the control, with no differences from those fed at $10 \%$ and $20 \%(\mathrm{P}>0.05)$. The mucosal length of the tilapia foregut significantly $(\mathrm{P}<0.05)$ increased in fish fed Azolla at $\mathbf{1 0 \%}$ compared to the control, with no differences from those fed at $\mathbf{2 0 \%}$ and $\mathbf{3 0} \%(\mathrm{P}>\mathbf{0 . 0 5})$. In the foregut and hindgut, the number of goblet cells significantly increased in fish fed Azolla at $3 \%$ compared to the control, with no differences from those fed at $10 \%$ and $20 \%$ $(\mathrm{P}>\mathbf{0 . 0 5})$, while in the midgut, the number of goblet cells significantly $(\mathrm{P}<0.05)$ increased in fish fed Azolla at $20 \%$ and $30 \%$ compared to the control, with no differences from those fed at $10 \%$ (P>0.05). Feeding tilapia with Azolla resulted in normal hematological and biochemical functions, with insignificant differences for the measured parameters except for the red blood cell count, which significantly $(\mathrm{P}<0.05)$ increased in fish fed Azolla at $20 \%$ compared to the control, with no differences from those fed at $20 \%$ and $30 \%$.
\end{abstract}

Key words: Azolla meal, digestive enzyme activity, genetically-improved farmed tilapia, intestinal morphometry, immune response 
Nile tilapia (Oreochromis niloticus) freshwater fish are easy to cultivate and resistant to disease, can live in tropical climates, and have high economic value (Dawood et al., 2019 a; Van Doan et al., 2019). GIFT are a particular strain, developed to be fast growing and adaptable to a wide range of environments (Dawood et al., 2019 b; Long et al., 2015). The increasing production and quality of tilapia continues to this day; therefore, feed is an important factor in increasing the growth and quality of GIFT (Amin et al., 2019; Dawood et al., 2019 c). In aquaculture, the cost of purchasing fish feed is quite high, so an alternative ingredient is needed that is cheap, easily available, and environmentally friendly (Sithara and Kamalaveni, 2008). The right feed ingredients can be extracted from water weeds, but to date, water weeds have been considered as waste; thus, the use of water weeds as substitute feed could facilitate the development of a new type of fishery production system.

Some types of aquatic weeds that can be used to feed tilapia, among others, are Lemna minor, Azolla pinnata, and Salvinia molesta (Nekoubin et al., 2013). Azolla as a source of plant protein (13-30\% dry weight protein) has a higher nutrient content than other types of water weeds, such as $S$. molesta (Das et al., 2018; Mithraja et al., 2011; Mosha, 2018; Sudaryono, 2006). Earlier studies have suggested that a $10-45 \%$ Azolla level can be incorporated in the diet of tilapia species, except for T. zillii, which requires more than $40 \%$ protein content (Abou et al., 2007; Djissou et al., 2017; Youssouf, 2012), while in fish belonging to the family Cyprinidae, the inclusion level should be $10-50 \%$ and $10-25 \%$ for Labeo rohita and the other family members, respectively (Kumari et al., 2017; Maity and Patra, 2008; Panigrahi et al., 2014), except for L. fimbriatus, which showed no effect with up to $40 \%$ Azolla inclusion in its diet.

Azolla pinnata, belonging to the family Azollaceae, grows in environments with the blue-green algae Anabaena azollae, which is considered to be a promising feed because of its high nutritive value, ease of cultivation, and high productivity (Maity and Patra, 2008; Prabina and Kumar, 2010). A. pinnata appears to be a good source of protein and contains almost all the essential amino acids, making it superior to wheat bran, maize, offal, and similar (Basak et al., 2002; Cherryl et al., 2014). Generally, the crude protein content of this plant species is in the range of $25 \%$ to $30 \%$ in dry matter, based on optimum growth conditions (Basak et al., 2002). Under natural conditions, protein values of $20 \%$ to $22 \%$ are frequent; therefore, the protein content of $A$. pinnata is comparable to, or higher than, that of most other aquatic macrophytes. The plant is naturally rich in minerals, such as iron, calcium, magnesium, potassium, phosphorus, and manganese, together with appreciable quantities of vitamin A, precursor beta-carotene, and vitamin $\mathrm{B}_{12}$ (Anitha et al., 2016). Azolla plants also contain some probiotics and biopolymers (Anitha et al., 2016).

In Egypt, the cost of feeding fish is about 70 percent of the total cost of farming. The high price and low availability of fish meal have increased the cost of pelleted feeds, in turn decreasing the profitability of tilapia farming; therefore, the present study aimed to evaluate the effect of the inclusion of Azolla on the growth performance, digestive enzyme activity, histomorphology, and health condition of GIFT. 


\section{Material and methods}

\section{Diet preparation}

After reviewing the Azolla inclusion levels used in previous studies (Abou et al., 2007; Djissou et al., 2017; Youssouf, 2012), four isonitrogenous and isolipidic diets were formulated to include $0 \%, 10 \%, 20 \%$, and 30\% Azolla powder (Table 1). All the ingredients were completely mixed, then water was added to produce a stiff dough. The dough was subsequently extruded using a pelleting machine with a die of 1 to $2 \mathrm{~mm}$, then the pellets were air-dried. The diets obtained were stored at $-20^{\circ} \mathrm{C}$ until they were used. A standard method was used to confirm the nutritional profile of the Azolla and test diets (AOAC, 2005) (Table 1).

Table 1. Basal diet and proximate chemical composition (on dry matter basis)

\begin{tabular}{l|c|c|c|c}
\hline \multirow{2}{*}{ Ingredient (\%) } & \multicolumn{4}{c}{ Test diet } \\
\cline { 2 - 5 } & Control & $10 \%$ & $20 \%$ & $30 \%$ \\
\hline Fish meal & 10 & 10 & 10 & 10 \\
Soybean meal & 38 & 35 & 31 & 29 \\
Azolla meal & 0 & 10 & 20 & 30 \\
Wheat bran & 10 & 8 & 7 & 6 \\
Yellow corn & 22 & 17 & 11 & 8 \\
Gluten & 3 & 3 & 3 & 3 \\
Rice bran & 10 & 10 & 11 & 7 \\
Oil & 5 & 5 & 5 & 5 \\
Dicalcium phosphate & 1 & 1 & 1 & 1 \\
Vitamins and minerals mixture & 1 & 1 & 1 & 1 \\
Chemical composition & & & & \\
Dry matter & 90.9 & 90.8 & 91.0 & 90.9 \\
Crude protein & 30.1 & 30.0 & 30.0 & 30.1 \\
Ether extract & 6.3 & 5.8 & 6.9 & 6.7 \\
Total ash & 7.7 & 9.6 & 12.1 & 13.0 \\
Crude fiber & 3.4 & 3.2 & 3.4 & 4.2 \\
Gross energy (KJ g ${ }^{-1}$ * & 18.6 & 18.2 & 18.0 & 17.7 \\
\hline
\end{tabular}

*Gross energy was calculated based on the values of values for protein, lipid and carbohydrate as 23.6, 39.5 and $17.2 \mathrm{~kJ} \mathrm{~g}^{-1}$, respectively.

\section{Fish and experimental protocol}

Nile tilapia were provided by a private farm in Kafrelsheikh Governorate, Egypt. The fish were kept for two weeks' adaptation on a basal diet (Table 1) before the experiment. Thereafter, 375 fish with similar body weight (initial body weight $11 \pm 0.01 \mathrm{~g})$ were distributed across 12 Habas (enclosures) $(0.5 \mathrm{~m}$ width $\times 1 \mathrm{~m}$ length $\times 0.5 \mathrm{~m}$ depth each, replicates), which were fixed in an earthen pond in a random manner, with 25 fish per Haba. The earthen ponds were provided with a running water system. The feeding rate was $3 \%$ of body weight and the fish were visually 
fed twice daily (08:00 and 16:00 h) during the acclimation period and feeding trial, which lasted for 90 days. The water temperature remained constant at $23.12 \pm 0.3^{\circ} \mathrm{C}$, and the $\mathrm{pH}$ varied in the range of 7.36-7.77. Dissolved oxygen and nitrite nitrogen were maintained above $6.00 \mathrm{mg} / \mathrm{L}$ and below $0.04 \mathrm{mg} / \mathrm{L}$, respectively, with photoperiods (12 h light:12 h darkness).

\section{Sampling schedule}

All the fish were starved for 24 hours before the sampling. The fish were quickly captured after being anesthetized with $100 \mathrm{mg} / \mathrm{L}$ tricaine methanesulfonate and weighed individually to obtain their final body weights (Dawood et al., 2019 d; Yarahmadi et al., 2014). Using a syringe without anticoagulant, blood samples were collected from the caudal blood vessels of three fish per Haba, and serum was separated by centrifuging the clotted blood at $3,000 \mathrm{rpm} / 15 \mathrm{~min}$ at $4^{\circ} \mathrm{C}$, then stored at $-20^{\circ} \mathrm{C}$. The collected serum samples were analyzed within 7 days to avoid spoilage of the samples. The intestines of nine fish from each group (three fish per Haba) were quickly removed and segments from the foregut, midgut, and hindgut were then placed in 10\% formalin for intestinal morphological analysis (Amin et al., 2019; Dawood et al., 2019 c). The collected fish were taken, and intestines were removed (nine fish per group), then washed with phosphate-buffered saline (PBS) (pH 7.5; $1 \mathrm{~g}$ per $10 \mathrm{~mL}$ ), homogenized, and centrifuged at 8,000 rpm for 5 minutes. The collected supernatant was then stored at $4^{\circ} \mathrm{C}$ until the preparation of the solutions that were required for the measuring of the digestive enzyme activity.

\section{Digestive enzyme activity}

The total protein content was measured by following Lowry et al. (1951) method, in which bovine serum albumin (BSA) was used as a standard. The protease activity was evaluated using Folin-Ciocalteu phenol reagent, and amylase activity was measured using iodine solution to detect non-hydrolyzed starch according to Jiang (1982) and Worthington (1993). The activity of protease and amylase was expressed as "units per mg of protein". On the basis of the protocol described by Borlongan (1990) and Jin (1995), with olive oil as a substratum, the specific activity of lipase was assessed and expressed as the intestinal content in "units per gram."

\section{Intestinal morphology}

Standard paraffin embedding procedures were used to stain each sample (three cross-sections) using hematoxylin-eosin (Bancroft et al., 1996). Intestinal morphology was determined by the height of the villus (from the tip of the villus to the villus crypt junction) and the depth of the crypt (from the villus crypt junction to the lower limit of the crypt), and the ratio of the height of the villus to the depth of the crypt (height of villus/depth of crypt) was measured using ImageJ software. A total of six wells, and random villi and villus-associated crypts, were determined for each intestinal cross-section. Goblet cells were stained with periodic acid-Schiff (PAS) and counted according to same-sized villi $(n=9)$. The results are shown as averages $( \pm \mathrm{SE})$ 


\section{Blood hematological, biochemical, and immune parameters}

Red blood cells (RBCs) and white blood cells (WBCs) were counted with a hemocytometer immediately after dilution with Natt and Herrick's solution (Houston, 1990). For the differential leucocytic count, blood films were prepared and stained according to Lucky (1977), while cells were calculated by following Jain (1986). For the hemoglobin assay, Drabkin's solution was added to the blood and the solution was then centrifuged $(3,500 \mathrm{~g}$ for $6 \mathrm{~min})$ to remove interferents. Thereafter, blood hemoglobin concentration was determined with a spectrophotometer (Model RA 1000, Technicon Corporation, USA) at $540 \mathrm{~nm}$ using Blaxhall and Daisley's (1973) method.

Serum total protein and albumin was determined according to Doumas et al. (1981) and Doumas and Biggs (1972). The globulin content was calculated mathematically. The activities of aspartate aminotransferase (AST) and alanine aminotransferase (ALT) were determined calorimetrically at a wavelength of $540 \mathrm{~nm}$ (Reitman and Frankel, 1957). Serum creatinine, urea, and bilirubin were calorimetrically determined according to Coulombe and Favreau (1963) and Heinegård and Tiderström (1973), respectively. Glucose (MG/100 ml) was determined using glucose enzymatic PAP kits obtained from Bio-Mérieux (France) (Trinder, 1969).

Blood lysozyme activity was determined using turbidimetric assay (Parry et al., 1965). Briefly, the lysozyme substrate consisted of $0.75 \mathrm{mg} / \mathrm{ml}$ of gram-positive $\mathrm{Mi}$ crococcus lysodeikticus lyophilized bacterium cells (Sigma, St. Louis, MO). The substrate was suspended in $0.1 \mathrm{M}$ sodium phosphate/citric acid buffer, $\mathrm{pH}$ 5.8. The serum samples $(25 \mu \mathrm{l})$ were placed, in triplicate, into a microtiter plate and $175 \mu \mathrm{l}$ of substrate solution was added to each well at $25^{\circ} \mathrm{C}$. The reduction in absorbance at $450 \mathrm{~nm}$ was read after 0 and 20 minutes using an ELX800G microplate ELISA reader (BioTek, VT, USA). The units of lysozyme present in the plasma or mucus $(\mu \mathrm{g} / \mathrm{ml})$ were obtained from a standard curve produced by lyophilized hen egg white lysozyme (Sigma).

Phagocytic activity was determined according to Kawahara et al. (1991). Briefly, $50 \mathrm{mg}$ Candida albicans culture was added to $1 \mathrm{ml}$ of blood sample and shaken in a water bath at $25^{\circ} \mathrm{C}$ for 5 hours. The blood smears were then stained with Giemsa stain solution. Phagocytosis was estimated by determining the proportion of macrophages that contained intracellular yeast cells in a random count of 300 macrophages and expressed as a percentage of phagocytic activity. To calculate the phagocytic index according to the following equations, the numbers of phagocytized and phagocytic cells were counted: Phagocytic activity $=$ macrophages containing yeast $/$ total number of macrophages $\times 100$; phagocytic index $=$ number of cells phagocytized/ number of phagocytic cells.

\section{Growth performance calculations}

All the fish per tank were weighed and counted separately during the final sampling. Weight gain (WG), specific growth rate (SGR), feed conversion ratio (FCR), and survival were evaluated. The following formulae were used: $\mathrm{WG}=(\mathrm{FBW}-$ $\mathrm{IBW}) \times 100 / \mathrm{IBW} ; \mathrm{SGR}(\mathrm{BW} /$ day $)=100((\mathrm{LnFBW}-\mathrm{LnIBW}) / \mathrm{T}) ; \mathrm{FCR}=\mathrm{FI} / \mathrm{WG}$; survival $=($ final number of fish/initial number $) \times 100$, where FBW $=$ final body 
weight (g), IBW = initial body weight $(\mathrm{g}), \mathrm{T}=$ duration of the trial in days, $\mathrm{WG}=$ wet weight gain $(\mathrm{g})$, and FI = estimated feed intake $(\mathrm{g})$.

\section{Statistical analysis}

Shapiro-Wilk and Levene tests confirmed the normal distribution and homogeneity of variance. The obtained data was subjected to a one-way ANOVA to evaluate the effect of dietary Azolla inclusion. Differences between the means were tested at the $5 \%$ probability level using a Duncan test as a post-hoc test. All the statistical analyses were conducted with SPSS version 22 (SPSS ${ }^{\circledR}$ Inc., IL, USA).

\section{Results}

\section{Growth performance and carcass composition}

The results of the growth performance are displayed in Table 2. The obtained results revealed that the final body weight, weight gain, and specific growth rate decreased significantly in fish fed $30 \%$ Azolla $(\mathrm{P}<0.05)$, while tilapia fed $10 \%$ and $20 \%$ did not differ significantly from those of the control $(\mathrm{P}>0.05)$. However, the feed conversion ratio increased significantly in fish fed $30 \%$ Azolla $(\mathrm{P}<0.05)$, while tilapia fed $10 \%$ and $20 \%$ did not differ significantly from those of the control $(\mathrm{P}>0.05)$. The body proximate analysis showed no effect of Azolla inclusion in tilapia diets, and the results were similar to those of the control group $(\mathrm{P}>0.05)$ (Table 3$)$.

Table 2. Growth performance, nutrient utilization and survival of GIFT fed test diets for 90 days*

\begin{tabular}{l|c|c|c|c}
\hline \multirow{2}{*}{\multicolumn{1}{c}{ Item }} & \multicolumn{4}{c}{ Test diet } \\
\cline { 2 - 5 } & Control & $10 \%$ & $20 \%$ & $30 \%$ \\
\hline Initial body weight & $11 \pm 0.01$ & $10.99 \pm 0.01$ & $11 \pm 0.01$ & $11 \pm 0.01$ \\
Final body weight & $31.03 \pm 0.14 \mathrm{~b}$ & $30.61 \pm 0.24 \mathrm{ab}$ & $30.22 \pm 0.11 \mathrm{ab}$ & $29.87 \pm 0.13 \mathrm{a}$ \\
Weight gain (\%) & $182.1 \pm 1.61 \mathrm{~b}$ & $178.46 \pm 2.34 \mathrm{ab}$ & $174.72 \pm 0.7 \mathrm{ab}$ & $171.56 \pm 0.9 \mathrm{a}$ \\
Specific growth rate & $1.73 \pm 0.01 \mathrm{~b}$ & $1.71 \pm 0.01 \mathrm{ab}$ & $1.69 \pm 0 \mathrm{ab}$ & $1.66 \pm 0.01 \mathrm{a}$ \\
Feed intake & $34.48 \pm 0.51$ & $34.41 \pm 0.3$ & $34 \pm 0.58$ & $33.9 \pm 0$ \\
Feed conversion ratio & $1.72 \pm 0.02 \mathrm{a}$ & $1.75 \pm 0.03 \mathrm{ab}$ & $1.77 \pm 0.02 \mathrm{ab}$ & $1.8 \pm 0.01 \mathrm{~b}$ \\
Survival & $97.5 \pm 1.44$ & $95.83 \pm 0.83$ & $96.67 \pm 1.67$ & $97.5 \pm 0$ \\
\hline
\end{tabular}

${ }^{*}$ Values expressed as means $\pm \mathrm{SE}(n=3)$. Different superscript letters indicate significant differences for each pairwise comparison between treatments.

Table 3. Body composition (as wet weight basis) in GIFT fed test diets for 90 days*

\begin{tabular}{l|r|r|r|r}
\hline \multirow{2}{*}{\multicolumn{1}{c}{ Item }} & \multicolumn{4}{c}{ Test diet } \\
\cline { 2 - 5 } & \multicolumn{1}{c}{ Control } & \multicolumn{1}{c}{$10 \%$} & \multicolumn{1}{c}{$20 \%$} & \multicolumn{1}{c}{$30 \%$} \\
\hline Crude protein & $26.15 \pm 0.29$ & $27.2 \pm 0.51$ & $26.85 \pm 0.64$ & $26.8 \pm 0.60$ \\
Total lipid & $16.43 \pm 0.21$ & $16.22 \pm 0.15$ & $16.3 \pm 0.31$ & $16.25 \pm 0.08$ \\
Ash & $2.15 \pm 0.04$ & $2.41 \pm 0.17$ & $2.3 \pm 0.27$ & $2.25 \pm 0.08$ \\
\hline
\end{tabular}

${ }^{*}$ Values expressed as means $\pm \mathrm{SE}(n=3)$. 


\section{Intestinal digestive enzymes and morphometric analysis}

The amylase, lipase, and protease activities were not significantly affected by Azolla inclusion in tilapia diets $(\mathrm{P}>0.05)$ (Figure 1); nor was the villus length of the foregut significantly affected by Azolla inclusion ( $\mathrm{P}>0.05$ ) (Figure 2). In the midgut, the villus length significantly $(\mathrm{P}<0.05)$ increased in fish fed Azolla at $20 \%$ and $30 \%$ compared to the control, with no differences from those fed at $10 \%(\mathrm{P}>0.05)$ (Figure 2). The villus length significantly $(\mathrm{P}<0.05)$ increased in the hind gut in fish fed Azolla at $30 \%$ compared to the control, with no differences from those fed at $10 \%$ and $20 \%(\mathrm{P}>0.05)$ (Figure 2).

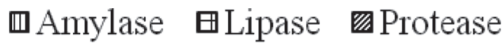

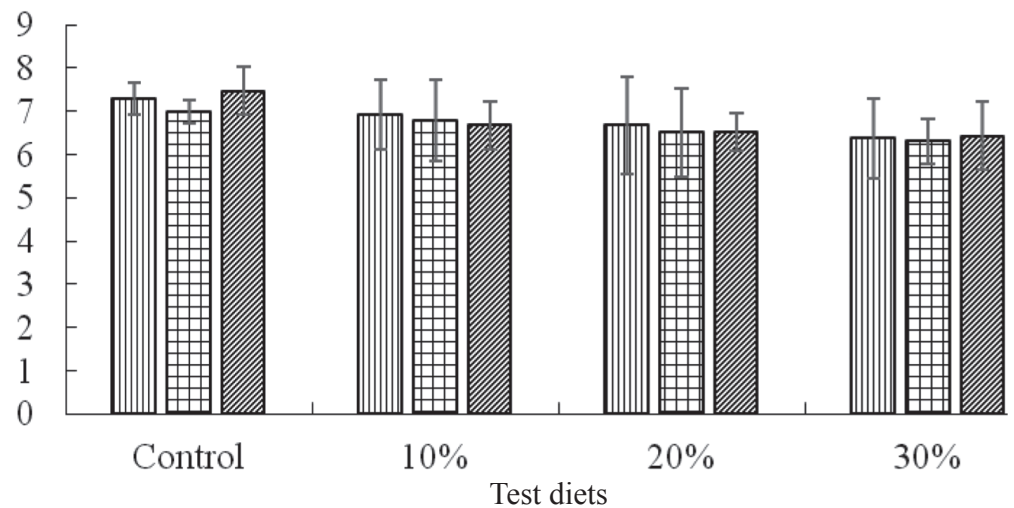

Figure 1. Intestinal digestive enzymes activities (U/mg) of GIFT fed test diets for 90 days. Values are expressed as mean $\pm \mathrm{SE}$ from triplicate groups. Bars without asterisks are non-significantly different from those of control group $(\mathrm{P}>0.05)$

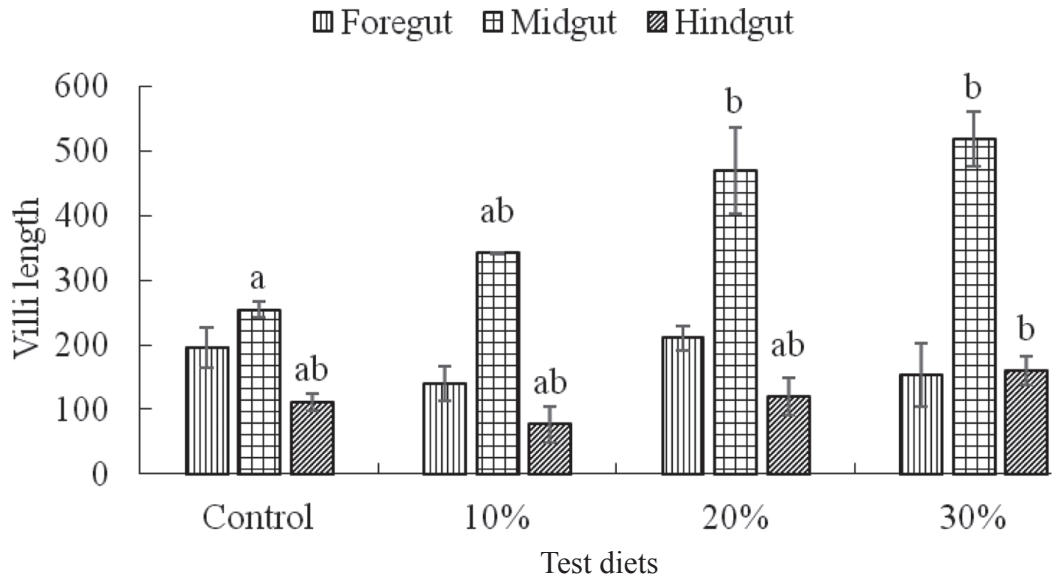

Figure 2. Intestinal villi length $(\mu \mathrm{m})$ of GIFT fed test diets for 90 days. Values are expressed as mean \pm SE from triplicate groups. Bars with an asterisk are significantly different from those of control group $(\mathrm{P}<0.05)$ 
The mucosal length of the tilapia foregut significantly $(\mathrm{P}<0.05)$ increased in fish fed Azolla at 10\% compared to the control, with no differences from those fed at $20 \%$ and $30 \%(\mathrm{P}>0.05)$ (Figure 3$)$. In the foregut and hindgut, the number of goblet cells significantly increased in fish fed Azolla at 30\% compared to the control, with no differences from those fed at $10 \%$ and $20 \%(\mathrm{P}>0.05)$, while in the midgut, the number of goblet cells significantly $(\mathrm{P}<0.05)$ increased in fish fed Azolla at $20 \%$ and $30 \%$ compared to the control, with no differences from those fed at $10 \%(\mathrm{P}>0.05)$ (Figure 3).

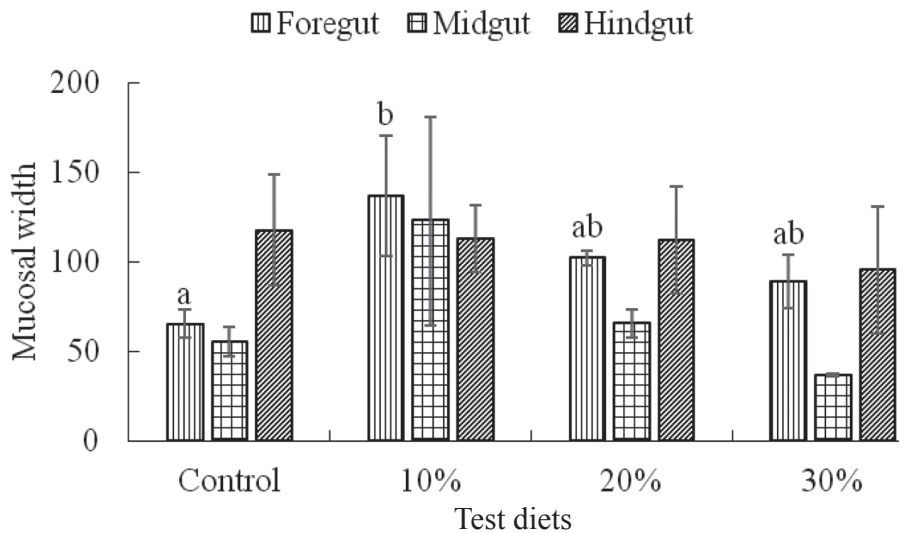

Figure 3. Mucosal length $(\mu \mathrm{m})$ of GIFT fed test diets for 90 days. Values are expressed as mean \pm SE from triplicate groups. Bars with an asterisk are significantly different from those of control group $(\mathrm{P}<0.05)$

The anterior, middle, and posterior parts of the fish intestines of the control and Azolla-treated groups exhibited normal structure; intact tunica mucosa, submucosa, muscularis, and serosa. Increases in the length, branching, and density of intestinal villi were evident in fish fed Azolla diets (Figure 6).

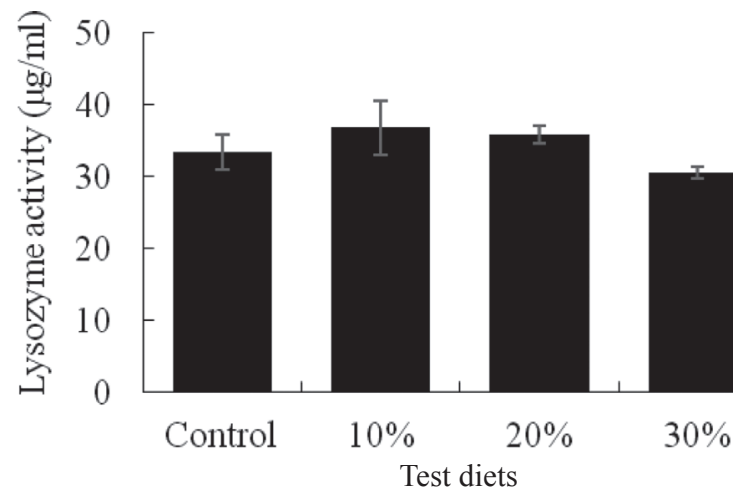

Figure 6. Lysozyme activity in GIFT fed test diets for 90 days. Values are expressed as mean $\pm \mathrm{SE}$ from triplicate groups. Bars without asterisks are non-significantly different from those of control group $(\mathrm{P}>0.05)$ 


\section{Blood hematological and biochemical analysis}

Feeding tilapia with Azolla resulted in normal blood hematological and biochemical results, with insignificant differences for the measured parameters, except for the red blood cell count, which significantly increased in fish fed Azolla at 20\% compared to the control, with no differences from those fed at $20 \%$ and $30 \%$ (Tables 4 and 5).

Table 4. Blood hematological parameters of GIFT fed test diets for 90 days*

\begin{tabular}{l|c|c|c|c}
\hline \multirow{2}{*}{ Item } & \multicolumn{4}{c}{ Test diet } \\
\cline { 2 - 5 } & Control & $10 \%$ & $20 \%$ & $30 \%$ \\
\hline $\mathrm{Hb}(\mathrm{g} / 100 \mathrm{ml})$ & $7.06 \pm 0.65$ & $8.62 \pm 1.52$ & $9.79 \pm 0.33$ & $9.26 \pm 0.46$ \\
$\mathrm{RBCs}\left(\times 10^{6} / \mu \mathrm{L}\right)$ & $2.39 \pm 0.2 \mathrm{a}$ & $3.13 \pm 0.53 \mathrm{ab}$ & $3.44 \pm 0.15 \mathrm{~b}$ & $2.96 \pm 0.04 \mathrm{ab}$ \\
WBCs $\left(\times 10^{3} / \mu \mathrm{L}\right)$ & $30.05 \pm 0.73$ & $36.1 \pm 5.01$ & $32.6 \pm 2.76$ & $31.42 \pm 1$ \\
Heterophils $(\%)$ & $7.33 \pm 0.88$ & $10.33 \pm 3.38$ & $7 \pm 0.58$ & $8 \pm 1.15$ \\
Lymphocyte $(\%)$ & $86.67 \pm 0.33$ & $80.67 \pm 3.18$ & $83.67 \pm 2.96$ & $84.67 \pm 2.73$ \\
Eosinophils $(\%)$ & $0.67 \pm 0.33$ & $1 \pm 0.58$ & $2.67 \pm 1.76$ & $0.67 \pm 0.33$ \\
Basophils $(\%)$ & $0.67 \pm 0.33$ & $1 \pm 0.58$ & $0.67 \pm 0.33$ & $0.67 \pm 0.07$ \\
PEV & $22.33 \pm 1.76$ & $26 \pm 4.04$ & $29.67 \pm 1.2$ & $27.33 \pm 0.88$ \\
MCV MCV $\left(\mathrm{mm}^{3}\right)$ & $93.67 \pm 0.76$ & $83.69 \pm 1.79$ & $86.47 \pm 3.21$ & $92 . .35 \pm 2.85$ \\
MCH $(\mathrm{Pg})$ & $29.54 \pm 0.35$ & $27.5 \pm 0.25$ & $28.52 \pm 0.3$ & $31.3 \pm 1.15$ \\
MCHC $(\%)$ & $31.54 \pm 0.63$ & $32.93 \pm 0.66$ & $33.07 \pm 1.14$ & $33.85 \pm 0.6$ \\
\hline
\end{tabular}

${ }^{*}$ Values expressed as means \pm SE $(n=3)$. Different superscript letters indicate significant differences for each pairwise comparison between treatments.

Table 5. Blood biochemical parameters of GIFT fed test diets for 90 days*

\begin{tabular}{|c|c|c|c|c|}
\hline \multirow{2}{*}{ Item } & \multicolumn{4}{|c|}{ Test diet } \\
\hline & Control & $10 \%$ & $20 \%$ & $30 \%$ \\
\hline $\operatorname{ALT}(\mathrm{U} / \mathrm{L})$ & $4.56 \pm 0.22$ & $10.67 \pm 6.39$ & $4.49 \pm 0.16$ & $4.55 \pm 0.1$ \\
\hline AST (U/L) & $81.82 \pm 1.29$ & $98.95 \pm 19.14$ & $82.16 \pm 1.49$ & $76.64 \pm 4.2$ \\
\hline Total protein $(\mathrm{mg} / \mathrm{dl})$ & $5.29 \pm 0.11$ & $5.08 \pm 0.43$ & $4.74 \pm 0.33$ & $5.47 \pm 0.25$ \\
\hline Albumin (mg/dl) & $3.5 \pm 0.21$ & $3.17 \pm 0.57$ & $2.91 \pm 0.46$ & $3.61 \pm 0.27$ \\
\hline Globulin (mg/dl) & $1.78 \pm 0.25$ & $1.91 \pm 0.16$ & $1.84 \pm 0.18$ & $1.86 \pm 0.02$ \\
\hline Urea (mg/dl) & $6.16 \pm 0.06$ & $6.38 \pm 0.26$ & $6.24 \pm 0.08$ & $6.19 \pm 0.05$ \\
\hline Creatinine (mg/dl) & $0.27 \pm 0.02$ & $0.27 \pm 0.02$ & $0.22 \pm 0.02$ & $0.22 \pm 0.02$ \\
\hline Uric acid (mg/dl) & $2.17 \pm 0.12$ & $2.25 \pm 0.13$ & $2.08 \pm 0.04$ & $2.22 \pm 0.09$ \\
\hline Glucose (mg/dl) & $14.26 \pm 0.17$ & $14.24 \pm 0.35$ & $14 \pm 0.36$ & $14.62 \pm 0.37$ \\
\hline Cholesterol (mg/dl) & $82.51 \pm 3.04$ & $80.33 \pm 5.38$ & $82.23 \pm 4.2$ & $79.82 \pm 1.61$ \\
\hline Triglyceride (mg/dl) & $139.97 \pm 2.68$ & $141.44 \pm 8.06$ & $144.74 \pm 3.11$ & $149.55 \pm 0.77$ \\
\hline
\end{tabular}

${ }^{*}$ Values expressed as means $\pm \mathrm{SE}(n=3)$. Different superscript letters indicate significant differences for each pairwise comparison between treatments. 


\section{Immune responses}

The blood phagocytic index, and the phagocytic and lysozyme activities, were not affected by Azolla inclusion in tilapia diets and they remained similar to those of the control group ( $\mathrm{P}>0.05)$ (Figures 4 and 5).

四Foregut $\boxplus$ Midgut Hindgut

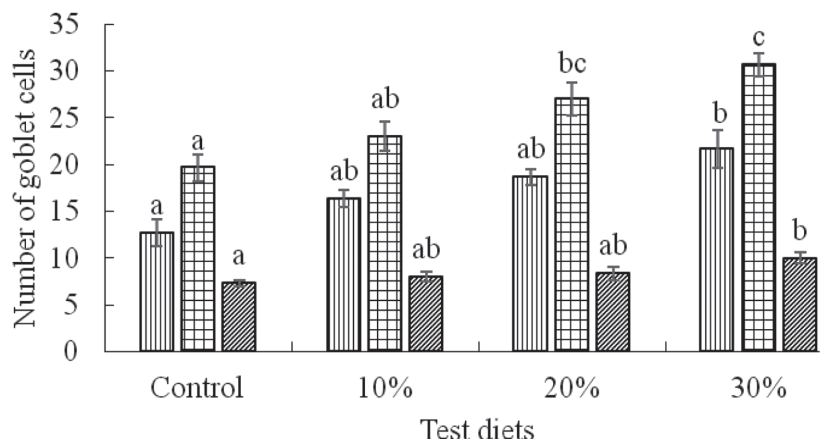

Figure 4. Number of goblet cells of GIFT fed test diets for 90 days. Values are expressed as mean \pm SE from triplicate groups. Bars with an asterisk are significantly different from those of control group $(\mathrm{P}<0.05)$

(A)

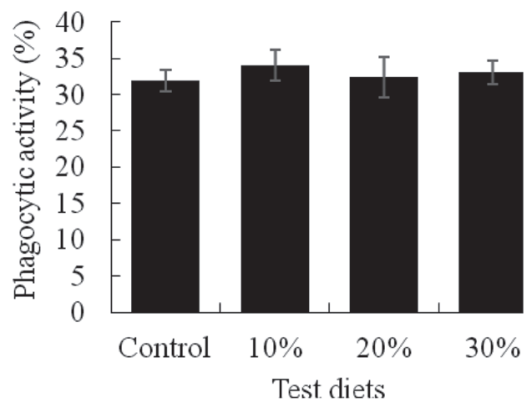

(B)

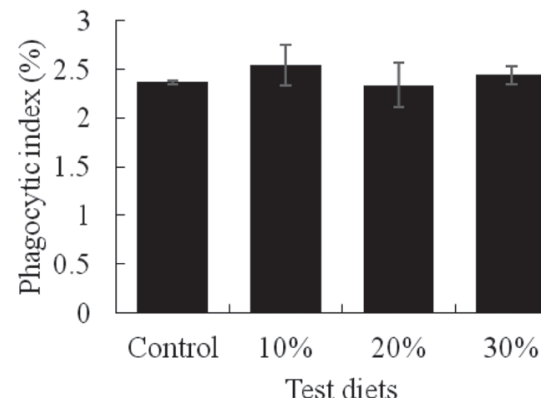

Figure 5. Phagocytic activity (A) and phagocytic index (B) of GIFT fed test diets for 90 days. Values are expressed as mean $\pm \mathrm{SE}$ from triplicate groups. Bars without asterisks are non-significantly different from those of control group $(\mathrm{P}>0.05)$ 

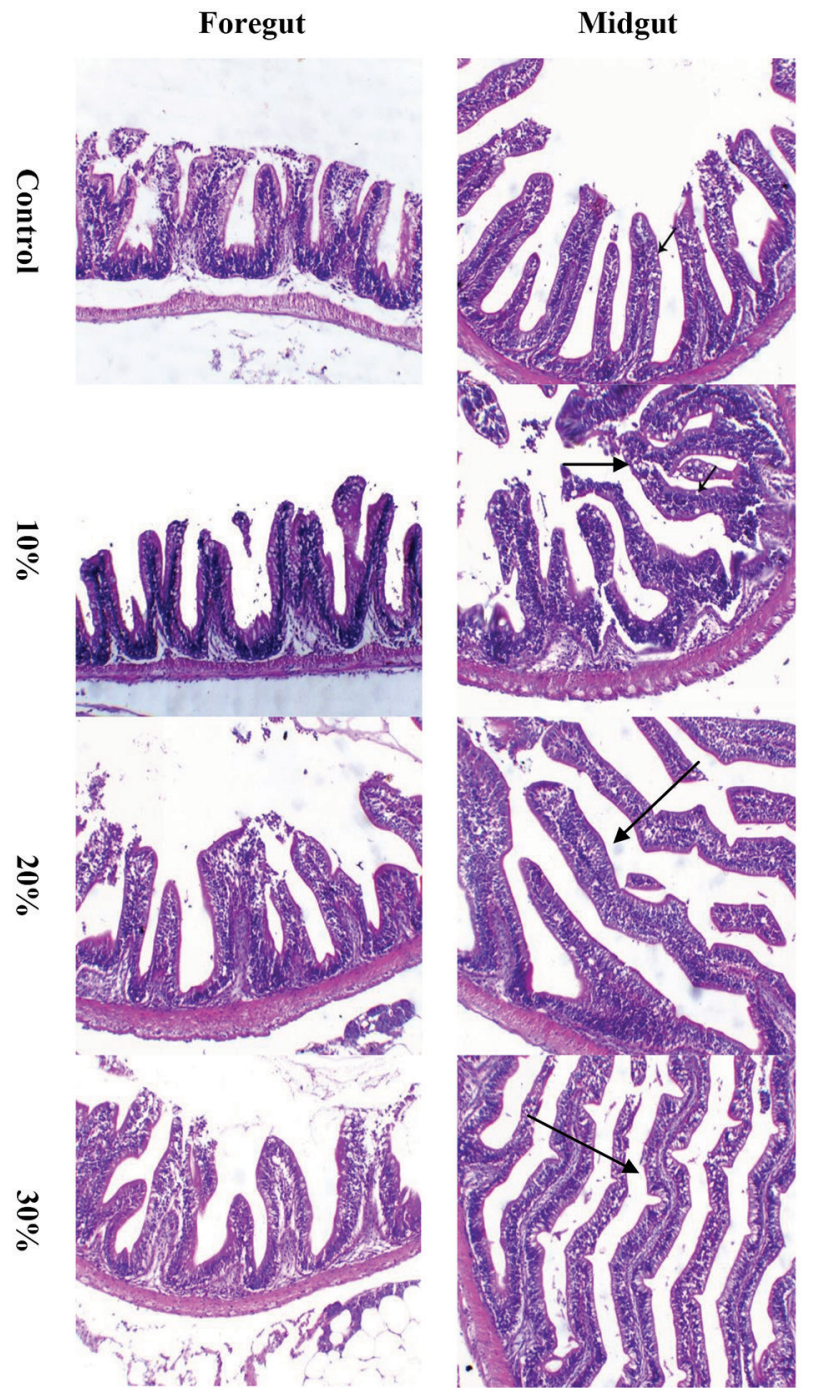

\section{Hindgut}
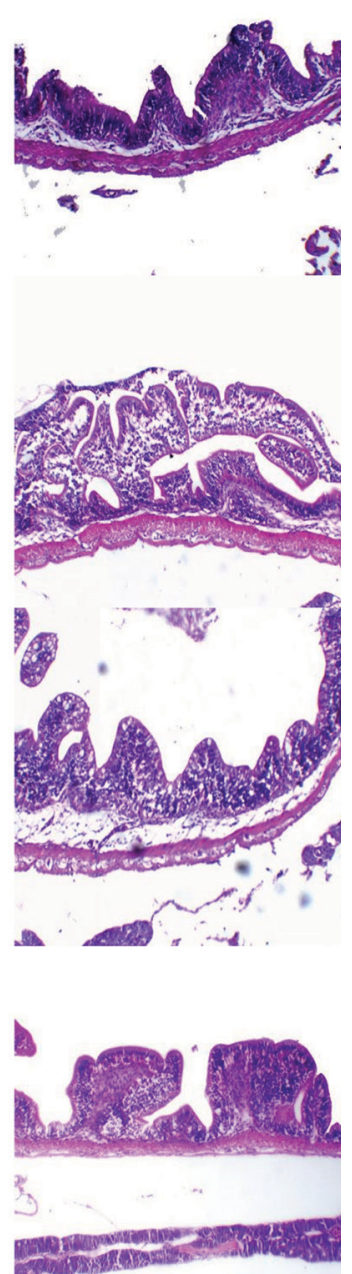

Figure 7. Intestinal morphology of fish fed the test diets (H\&E, X100). The intestine of fish fed on Azolla showing increase the density of intestinal villi. The intestine of fish fed on Azolla showing increase in the length and branching intestinal villi (arrow)

\section{Discussion}

Selection of feed ingredients is one of the most important factors for the formulation and commercial production of aquafeeds (Dawood and Koshio, 2019; Dossou et al., 2019). Although fish meal is a widely used feed ingredient as an animal protein 
source and valued for its high protein composition and essential amino acids, it is more expensive than the available plant protein sources (Bairagi et al., 2002; Dossou et al., 2018 a). In addition, the availability of fish meal is steadily decreasing, due to the high demand for it in other industries than aquaculture, such as livestock or poultry farming. The decreased supply of fish meal in the future will dramatically affect fish production; hence, it is essential to partially reduce or completely eliminate fish meal in fish diets. One approach to reducing fish meal in fish diets is to replace it with alternative, less expensive, non-traditional, and readily-available plant protein, which will allow for the continued expansion of aquaculture. Consequently, a number of plant protein sources have been evaluated as replacements for fish meal (Dawood et al., 2015; Dossou et al., 2018 b; Gatlin III et al., 2007). The proximate composition of Azolla meal relates to its high content of crude protein and essential amino acids (especially lysine). In the current study, all the experimental feeds were actively fed to and accepted by the fish throughout the experimental period, which could be as a result of the palatability of the feed, indicating that the levels of incorporation of Azolla did not affect the palatability of the diets. Furthermore, the final body weight, weight gain, and specific growth rate parameters did not decline with up to $20 \%$ inclusion of Azolla in tilapia diets. Interestingly, Das et al. (2018) reported improved growth performance at a similar inclusion level (25\%) for common carp fed Azolla. The level of Azolla required to give maximum growth performance may vary according to Azolla inclusion levels, periods of administration, experimental procedures, and fish species and sizes.

Significant decreases in growth performance were evident for the higher inclusion level of Azolla (30\%) in the present study. Azolla has high fiber and antinutritional factors (ANFs), which may negatively affect the feed efficiency of fish, and hence the growth performance (Kamali-Sanzighi et al., 2019; Li et al., 2012). High levels of Azolla have been shown to reduce weight by increasing both the metabolic rate and energy expenditure, while decreasing the digestibility of ingredients, due to its ANF content (e.g., tannin, catechin monomers, and caffeine) (Ahmed et al., 2017; Habib et al., 2014; Mohammadi et al., 2018). Azolla has been found to exert an influence upon the emulsion interface, interacting with digestive enzymes to decrease feed utilization and growth performance (Sotolu et al., 2013).

The activities of digestive enzymes (lipase, amylase, and protease) observed in the current study were the main factors that helped fish to digest Azolla efficiently, without reducing the feed intake. High levels of Azolla inclusion may weaken the digestion and feed consumption by affecting digestive enzyme activity (Hong et al., 2004; Sithara and Kamalaveni, 2008); thus, the growth performance may be associated with the improved digestibility of nutrients and feed efficiency.

Morphometric measurement of the heights and widths of intestinal villi, as well as the number of goblet cells, can help in predicting the absorption and digestion mechanisms in fish guts (Dawood et al., 2019 d; Lauriano et al., 2016; Rašković et al., 2011; Trischitta and Faggio, 2008). The measured villous length and width of the three intestinal sections were enlarged in fish fed Azolla in the present study. The villi surface areas for nutrient absorption in animals can be enhanced if the size of the tunnels, the number of villi, and the height of the intestinal villus are increased (Caspary, 
1992). Furthermore, Azolla contains high levels of crude protein and essential amino acids that can improve the intestinal absorptive capacity, decrease scours, and enhance the growth of fish (Cherryl et al., 2014; Hong et al., 2004; Mosha, 2018). The enhanced feed utilization of fish fed Azolla can be attributed to the content in intestinal cells of protein that improves the metabolism and absorption of nutrients (Mello et al., 2013). The improved intestinal morphology in this study could be explained by the Azolla increasing cell proliferation and protein synthesis. Overall, Azolla positively increased the ability of tilapia to digest diets more efficiently, which in turn increased the growth performance.

Besides their role in the digestion process, the intestinal goblet cells can excrete mucous and antibacterial substances that protect the mucosal layer from dehydration, damage, and pathogens (Noga, 1996; Pirarat et al., 2015). These antibacterial substances contain glycoproteins and low molecular weight fatty acids that affect the lysozyme activity (Junqueira and Carneiro, 2005). The number of goblet cells in fish intestines is affected by the richness of the diet and its nutritional value, as well as environmental stressors (e.g., pathogens and rearing conditions) (Schwarz et al., 2010). The inclusion of Azolla in this study resulted in an increased number of goblet cells, which may improve immunity and resistance to infectious diseases.

Hematological, biochemical, and physiological markers could be utilized to recognize the probable nutritional effects on the health of aquatic animals (BurgosAceves et al., 2019; Dawood et al., 2016, 2019 d, 2020; Faggio et al., 2014 a, b). The hematology and biochemical variables measured in the current study revealed stable and normal values, showing the non-harmful effect of Azolla inclusion in tilapia diets. The improved RBC values indicated that the fish were free of anemia as a result of Azolla feeding. Inclusion of Azolla improved hematological parameters compared with the control and other groups in this study (20\%). It was assumed that dietary Azolla could positively ameliorate most of the blood indices in fish as a result of improved immunity. The presence of Azolla helped to improve the immune function in fish blood by activating the immunity of intestinal barriers.

In the present study, the serum lysozyme activity was insignificantly affected by Azolla inclusion compared to the control. Saurabh and Sahoo (2008) linked the increase in the lysozyme activity of fish to the abundance of cells related to the immune system; monocytes, macrophages, and polymorphonucleated granulocytes are the main source of such proteolytic enzymes. In addition, the increase in lysozyme in the blood of stimulated fish is associated either with proliferating phagocytes or increased amounts of lysozymes produced from lysosomes, rendering lysozyme activity one of the best markers for evaluating the bactericidal effect of the diets' nutritional value. A similar improvement in blood phagocytosis was observed in the current study through Azolla feeding. Phagocytosis is recognized as an immune defensive component that helps fish to avoid the risk of infectious diseases (Harikrishnan et al., 2011). The obtained results confirmed that Azolla inclusion can maintain the immune responses (lysozyme activity and phagocytosis) that facilitate resistance to pathogens. 


\section{Conclusion}

It is obvious that Azolla has beneficial effects on the digestive enzymes, intestinal morphometry, immune functions, and growth performance of GIFT. Considering the low price of Azolla, the results obtained showed the importance of including Azolla in tilapia diets. The optimal inclusion levels, based on the obtained results, ranged from 10 to $20 \%$ of the diet.

\section{References}

A b o u Y., F i o g b é E.D., M i c h a J.C. (2007). A preliminary assessment of growth and production of Nile tilapia, Oreochromis niloticus L., fed Azolla-based-diets in earthen ponds. J. Appl. Aquacult., 19: 55-69.

Ahmed V.M., Abdulrahman N.M., Ham A meen S.A., Rafiq B., Has san A.B.K.A., Hu s se n B.A., H a mad I.S., Ka re m S.A., A z i z K.M. (2017). Impacts of date palm seeds (Phoenix dactyliferous L.) on growth indices and nutrient utilization of common carp Cyprinus carpio L. J. Agric. Sci. Technol. B, 7: 280-284.

Amin A., El Asely A., Abd E1-Naby A.S., Samir F., E1-A shram A., Sudhakar a n R., D a w o o d M.A.O. (2019). Growth performance, intestinal histomorphology and growthrelated gene expression in response to dietary Ziziphus mauritiana in Nile tilapia (Oreochromis niloticus). Aquaculture, 512: 734301.

Anitha K.C., Rajeshwar i Y.B., Pras ann a S.B., Shree J.S. (2016). Nutritive evaluation of Azolla as livestock feed. J. Exp. Biol. Agricult. Sci., 4: 670-674.

AOAC (2005). Official Methods of Analysis, 18th ed. Association of Official Analytical Chemists. AOAC International, Maryland, USA.

B a irag i A., Ghosh K.S., Sen S., Ray A. (2002). Duckweed (Lemna polyrhiza) leaf meal as a source of feedstuff in formulated diets for rohu (Labeo rohita Ham.) fingerlings after fermentation with a fish intestinal bacterium. Bioresour. Technol., 85: 17-24.

B a n croft J., Stevens A., Turner D. (1996). Theory and practice of histological techniques: Churchill Livingstone, New York. 766.

B a sak B., Pramanik M.A.H., Rahman M.S., Tarafdar S.U., Roy B.C. (2002). Azolla (Azolla pinnata) as a feed ingredient in broiler ration. Int. J. Poult. Sci., 1: 29-34.

B 1 a x hall P.C., D a is ley K.W. (1973). Routine haematological methods for use with fish blood. J. Fish Biol., 5: 771-781.

B or lo ng a I.G. (1990). Studies on the digestive lipases of milkfish, Chanos chanos. Aquaculture, 89: 315-325.

Burgos-Aceves M.A., Lionetti L., Fagg i o C. (2019). Multidisciplinary haematology as prognostic device in environmental and xenobiotic stress-induced response in fish. Sci. Total Environ., 670: 1170-1183.

C a s pary W.F. (1992). Physiology and pathophysiology of intestinal absorption. Oxford University Press.

Cherryl D.M., Prasad R.M.V., Jagadeeswara Rao S., J a y laxmi P., Srinivas Kum a r D. (2014). A study on the nutritive value of Azolla pinnata. Livest. Res. Int., 2: 13-15.

C o u 1 o m b e J.J., F a vre a u L. (1963). A new simple semimicro method for colorimetric determination of urea. Clin. Chem., 9: 102-108.

D a s M., R a h im F., Hos s a in M. (2018). Evaluation of fresh Azolla pinnata as a low-cost supplemental feed for Thai Silver Barb Barbonymus gonionotus. Fishes, 3: 15.

D a w o o d M.A.O., K o s h i o S. (2019). Application of fermentation strategy in aquafeed for sustainable aquaculture. Rev. Aquacult., https://doi.org/10.1111/raq.12368

D a w o od M.A.O., K o s h i o S., I s h i k a w a M., Yo k o y a m a S. (2015). Effects of partial substitution of fish meal by soybean meal with or without heat-killed Lactobacillus plantarum (LP20) on growth performance, digestibility, and immune response of amberjack, Seriola dumerili juveniles. Biomed Res. Int., 2015: 11. 
D aw o o d M.A.O., K o s hi o S., I s hikaw a M., Yok o y a ma S. (2016). Effects of dietary inactivated Pediococcus pentosaceus on growth performance, feed utilization and blood characteristics of red sea bream, Pagrus major juvenile. Aquacult. Nutr., 22: 923-932.

D aw o o d M.A.O., Shukry M., Z ayed M.M., O mar A.A., Zaineld in A.I., E 1 B a s u i n i M.F. (2019 a). Digestive enzymes, immunity and oxidative status of Nile tilapia (Oreochromis niloticus) reared in intensive conditions. Slov. Vet. Res., 56.

D a w o o d M.A.O., Ma g o u z F.I., S a l e m M.F.I., A b d e l- D a i m H.A. (2019 b). Modulation of digestive enzyme activity, blood health, oxidative responses and growth-related gene expression in GIFT by heat-killed Lactobacillus plantarum (L-137). Aquaculture, 505: 127-136.

Dawo od M.A.O., Z ommara M., Eweedah N.M., Helal A.I. (2019 c). The evaluation of growth performance, blood health, oxidative status and immune-related gene expression in Nile tilapia (Oreochromis niloticus) fed dietary nanoselenium spheres produced by lactic acid bacteria. Aquaculture, 515: 734571.

D aw o o d M.A.O., Ew e e d a h N.M., Mous ta fa M.E., Shah in M.G. (2019 d). Effects of feeding regimen of dietary Aspergillus oryzae on the growth performance, intestinal morphometry and blood profile of Nile tilapia (Oreochromis niloticus). Aquacult. Nutr., 25: 1063-1072.

D a w o o d M.A.O., M g g o u z F.I., S a l e m M.F.I., E 1 b i a ly Z.I., A b d e 1 - D a i m H.A. (2019 e). Synergetic effects of Lactobacillus plantarum and beta-glucan on digestive enzyme activity, intestinal morphology, growth, fatty acid, and glucose-related gene expression of genetically improved farmed tilapia. Probiotics Antimicrob. Proteins, 12: 389-399.

D a w o o d M.A.O., E w e e d a h N.M., E 1 b i a ly Z.I., A b d e 1 h a m i d A.I. (2020). Dietary sodium butyrate ameliorated the blood stress biomarkers, heat shock proteins, and immune response of Nile tilapia (Oreochromis niloticus) exposed to heat stress. J. Therm. Biol., 88: 102500.

D j i s s ou A.S., O c hi a i A., K o s h i o S., F i o g b é E.D. (2017). Effect of total replacement of fishmeal by earthworm and Azolla filiculoides meals in the diets of Nile tilapia Oreochromis niloticus (Linnaeus, 1758) reared in concrete tanks. Indian J. Fish., 64: 31-36.

Dossou S., Koshio S., Ishikawa M., Yokoyama S., Dawood M.A.O., E1 Basuin i M.F., E1-Ha is A.M., Olivi er A. (2018 a). Effect of partial replacement of fish meal by fermented rapeseed meal on growth, immune response and oxidative condition of red sea bream juvenile, Pagrus major. Aquaculture, 490: 228-235.

Dos sou S., Koshio S., Ishikawa M., Yokoyama S., Dawood M.A.O., E1 Basuin i M.F., O livi e r A., Z a in e l d in A.I. (2018 b). Growth performance, blood health, antioxidant status and immune response in red sea bream (Pagrus major) fed Aspergillus oryzae fermented rapeseed meal (RM-Koji). Fish Shellfish Immunol., 75: 253-262.

Dossou S., Koshio S., Ishikawa M., Yokoyama S., E1 Basuini M.F., Zaine1d i n A.I., M z e n g e r e z a K., M o s s A., D a w o o d M.A.O. (2019). Effects of replacing fishmeal with fermented and non-fermented rapeseed meal on the growth, immune and antioxidant responses of red sea bream (Pagrus major). Aquacult. Nutr., 25: 508-517.

D o u m a s B.T., B igg s H.G. (1972). Editors. Standard Methods of Clinical Chemistry. Academic Press, New York.

D ou ma s B.T., B ay s e D.D., C arter R.J., P eters T., S chaffer R. (1981). A candidate reference method for determination of total protein in serum. I. Development and validation. Clin. Chem., 27: 1642-1650.

F a g g i o C., F ed e le G., A r fus o F., Panzera M., F a zi o F. (2014 a). Haematological and biochemical response of Mugil cephalus after acclimation to captivity. Cah. Biol. Mar., 55: 31-36.

F a g gio C., P i c cione G., Marafiot i S., Arfus o F., Fortino G., F a zi o F. (2014 b). Metabolic response to monthly variations of Sparus aurata reared in Mediterranean on-shore tanks. Turk. J. Fish. Aquat. Sci., 14: 567-574.

G at 1 i n I I I D.M., B a rrow s F.T., B row n P., D a brow s ki K., G a y lord T.G., Hard y R.W., Herman E., Hu G., Krog dahl Å., N els on R. (2007). Expanding the utilization of sustainable plant products in aquafeeds: a review. Aquacult. Res., 38: 551-579.

Habib H.M., P lat at C., Meudec E., Cheynier V., Ibrahim W.H. (2014). Polyphenolic compounds in date fruit seed (Phoenix dactylifera): characterisation and quantification by using UPLC-DAD-ESI-MS. J. Sci. Food Agric., 94: 1084-1089.

Harikrishnan R., K i m J.-S., K i m M.-C., B a l a s und a r a m C., H e o M.-S. (2011). Prunella 
vulgaris enhances the non-specific immune response and disease resistance of Paralichthys olivaceus against Uronema marinum. Aquaculture, 318: 61-66.

H e i n e g å r d D., Ti d e r s tr ö m G. (1973). Determination of serum creatinine by a direct colorimetric method. Clin. Chim. Acta, 43: 305-310.

H o n g K.-J., L e e C.-H., K i m S.W. (2004). Aspergillus oryzae GB-107 fermentation improves nutritional quality of food soybeans and feed soybean meals. J. Med. Food, 7: 430-435.

H o u s t o n A. (1990). Blood and circulation/Methods for fish biology. NY. Amer. Fish. Society.

J a in N.C. (1986). Schalm's Veterinary Hematology. Lea \& Febiger, Philadelphia, pp. 21-62.

J i a n C. (1982). Activity measuring for implemental enzyme. Science and Technology Press, Shanghai.

J in Z. (1995). The evaluation principle and method of functional food. Beijing Publishers.

J u n qu e ir a L.C.U., C arn eir o J. (2005). Basic histology: text \& atlas. McGraw-Hill Professional.

K a ma li - S a nzigh i M., A krami R., Gheli ch i A., Sh a m lo of a r M. (2019). Partial replacement of plant sources by waste date (Phoneix dactylifera) in the diet of fingerling common carp (Cyprinus carpio) on growth performance, feed utilization, hematological parameters and resistance to stress. Turk. J. Fish. Aquat. Sci., 19: 775-784.

K a wah ar a E., U ed a T., N o mur a S. (1991). In vitro phagocytic activity of white-spotted char blood cells after injection with Aeromonas salmonicida extracellular products. Fish Pathol., 26: 213-214.

K u mar i R., Ojh a M., S a in i V., S h a r m a S.J.J.E.Z.S. (2017). Effect of Azolla supplementation on growth of rohu (Labeo rohita) fingerlings. J. Entomol. Zool. Stud., 5: 1116-1119.

Lauriano E.R., Pergolizzi S., Capillo G., Kuciel M., Alesci A., Fagg io C. (2016). Immunohistochemical characterization of Toll-like receptor 2 in gut epithelial cells and macrophages of goldfish Carassius auratus fed with a high-cholesterol diet. Fish Shellfish Immunol., 59: 250-255.

L i S., I r i s M.Y., L i E.T. (2012). Maternal green tea extract supplementation to rats fed a high-fat diet ameliorates insulin resistance in adult male offspring. J. Nutr. Biochem., 23: 1655-1660.

L o n g L., Yang J., L i Y., G u a n C., W u F. (2015). Effect of biofloc technology on growth, digestive enzyme activity, hematology, and immune response of genetically improved farmed tilapia (Oreochromis niloticus). Aquaculture, 448: 135-141.

L ow ry O.H., Rosebrough N.J., F arr A.L., R an dall R.J. (1951). Protein measurement with the Folin phenol reagent. J. Biol. Chem., 193: 265-275.

L u c k y Z. (1977). Methods for the diagnosis of fish diseases. Amerind. Publishing Co. PV T. Ltd., New Delhi, Bombay, India.

Maity J., Patra B.C. (2008). Effect of replacement of fishmeal by Azolla leaf meal on growth, food utilization, pancreatic protease activity and RNA/DNA ratio in the fingerlings of Labeo rohita (Ham.). Can. J. Pure Appl. Sci., 323.

Mello H.D., Morae s J., Niza I.G., Mora es F.R.D., Ozório R., Shimada M.T., Engrac i a F., C l a u di a no G. (2013). Efeitos benéficos de probióticos no intestino de juvenis de Tilápia-do-Nilo. Pesqui Vet. Bras., 33: 724-730.

Mithraja M.J., Marimuthu J., Mahesh M., Paul Z.M., Jeeva S. (2011). Phytochemical studies on Azolla pinnata R. Br., Marsilea minuta L. and Salvinia molesta Mitch. Asian Pac. J. Trop. Biomed., 1: S26-S29.

Mohammadi M., Soltani M., Siahpoosh A., Hosseini Shekarabi S.P., Shamsaie Mehrgan M., Lymber A. (2018). Effect of date palm (Phoenix dactylifera) seed extract as a dietary supplementation on growth performance immunological haematological biochemical parameters of common carp. Aquacult. Res., 49: 2903-2912.

M o s h a S. (2018). A review on significance of azolla meal as a protein plant source in finfish culture. J. Aquac. Res. Develop., 9: 2.

N e k o u b in H., S u d a g a r M. (2013). Effect of different types of plants (Lemna sp., Azolla filiculoides and alfalfa) and artificial diet (with two protein levels) on growth performance, survival rate, biochemical parameters and body composition of grass carp (Ctenopharyngodon idella). J. Aquac. Res. Develop., 4: 2.

Nog a E. (1996). Fish Desease: Diagnosis and Treatment. St. Louis, Missouri. Mosby-Year Book. Inc. 
Panigrahi S., Choudhury D., S ahoo J.K., D a s S.S., R a th R.K. (2014). Effect of dietary supplementation of Azolla on growth and survivability of Labeo rohita fingerlings. Asian J. Anim. Sci., 9: 33-37.

Parry J., Rich ard M., Chand an R.C., Shah an i K.M. (1965). A rapid and sensitive assay of muramidase. Proc. Soc. Exp. Biol. Med., 119: 384-386.

Pirarat N., B oonananthanasarn S., Krongpong L., Katagiri T., Maita M. (2015). Effect of activated charcoal-supplemented diet on growth performance and intestinal morphology of Nile tilapia (Oreochromis niloticus). Thai. J. Vet. Med., 45: 113-119.

Prabina B.J., Kumar K. (2010). Dried Azolla as a nutritionally rich cost effective and immunomodulatory feed supplement for broilers. Asian J. Anim. Sci., 5: 20-22.

Rašković B.S., Stanković M.B., Marković Z.Z., Poleksić V.D. (2011). Histological methods in the assessment of different feed effects on liver and intestine of fish. J. Agric. Sci., 56: $87-100$.

Reitman S., Frankel S. (1957). A colorimetric method for the determination of serum glutamic oxalacetic and glutamic pyruvic transaminases. Am. J. Clin. Pathol., 28: 56-63.

S a u r a bh S., S a ho o P. (2008). Lysozyme: an important defence molecule of fish innate immune system. Aquacult. Res., 39: 223-239.

S chwarz K., Furuy a W., N a ta li M., Mich el a to M., Guald e zi M. (2010). Mannanoligosaccharides in diets for Nile tilapia, juveniles. Acta Sci. Anim., 32: 197-203.

$\mathrm{S}$ i th a r a K., K a m a lave n i K. (2008). Formulation of low-cost feed using azolla as a protein supplement and its influence on feed utilization in fishes. Current Biotica, 2: 212-219.

S o t o 1 u A., K i g b u A., O s h i n o w o A. (2013). Supplementation of date palm (Phoenix dactylifera) seed as feed additive in the diets of juvenile African catfish (Burchell, 1822). J. Fish. Aquatic Sci., 9: 359-365.

S u d a ry o n o A. (2006). Use of Azolla (Azolla pinnata) meal as a substitute for defatted soybean meal in diets of juvenile black tiger shrimp (Penaeus monodon). J. Coast. Dev., 9: 145-154.

Trin d e r P. (1969). Determination of glucose in blood using glucose oxidase with an alternative oxygen acceptor. Ann. Clin. Biochem., 6: 24-27.

Tris chitta F., F aggi o C. (2008). Gossypol affects ion transport in the isolated intestine of the seawater adapted eel, Anguilla anguilla. Comp. Biochem. Physiol. A Mol. Integr. Physiol., 151: $139-143$.

Van Doan H., Hos einifar S.H., Sringarm K., Jaturasitha S., Yuangsoi B., Daw o o d M.A.O., E s t e b a n M.Á., R i n g ø E., F a g g i o C. (2019). Effects of Assam tea extract on growth, skin mucus, serum immunity and disease resistance of Nile tilapia (Oreochromis niloticus) against Streptococcus agalactiae. Fish Shellfish Immunol., 93: 428-435.

Worthington V. (1993). Worthington enzyme manual: enzymes and related biochemicals. Worthingthon Chemical. New Jersey, p. 399.

Yarahmadi P., Miandare H.K., Farahmand H., Mirvaghefi A., Hoseinifar S.H. (2014). Dietary fermentable fiber upregulated immune related genes expression, increased innate immune response and resistance of rainbow trout (Oncorhynchus mykiss) against Aeromonas hydrophila. Fish Shellfish Immunol., 41: 326-331.

You s s o u f A. (2012). Water quality and sediment features in ponds with Nile tilapia (Oreochromis niloticus L.) fed Azolla. J. Fish. Aquaculture, 3: 47.

Received: 15 XI 2019

Accepted: 14 I 2020 